\title{
Pulmonary sequestration in an adult patient without prior pulmonary conditions
}

\author{
Kento Sonoda, ${ }^{1}$ Norman Randy Kolb, ${ }^{1}$ Yasuharu Tokuda (i) ${ }^{2}$
}

${ }^{1}$ Family Medicine, University of Pittsburgh Medical Center, Pittsburgh, Pennsylvania, USA ${ }^{2}$ General Internal Medicine, Muribushi Okinawa Center for Teaching Hospitals, Okinawa, Japan

\section{Correspondence to}

Professor Yasuharu Tokuda; yasuharu.tokuda@gmail.com

Accepted 7 November 2021

D Check for updates

(c) BMJ Publishing Group Limited 2021. No commercial re-use. See rights and permissions. Published by BMJ.

To cite: Sonoda K, Kolb NR, Tokuda Y. BMJ Case

Rep 2021;14:e246835.

doi:10.1136/bcr-2021-

246835

\section{DESCRIPTION}

A 36-year-old man with peptic ulcer disease presented to the emergency department with a 2-day history of haemoptysis and cough. Though he had no prior pulmonary symptoms, he noted progressive chest tightness and shortness of breath. He had no fever or night sweats. Vital signs were afebrile and normotensive without tachycardia and tachypnoea. Physical examination was notable for diminished breath sounds at the left posterior base without coarse crackles. Electrocardiogram did not

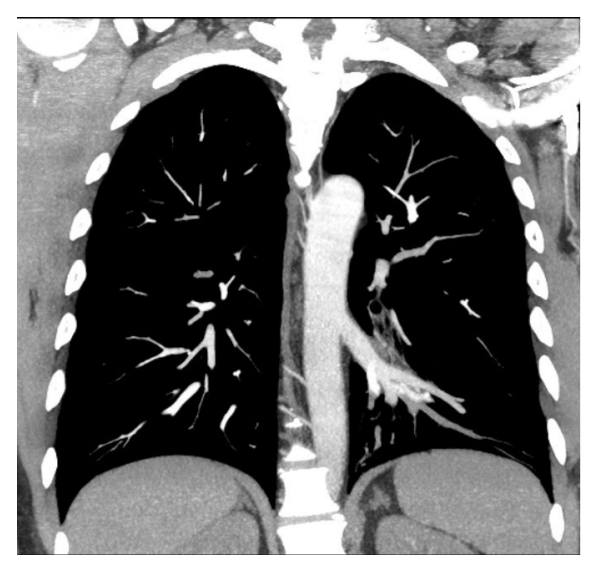

Figure 1 A CT angiography of the chest showing anomalous systemic arterial supply from the descending aorta to the left lower lobe basal segments.

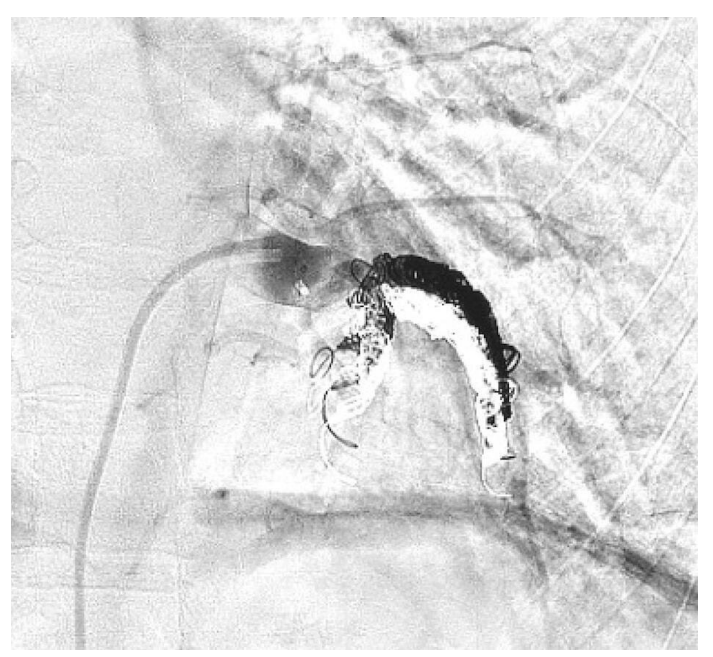

Figure 2 Digital subtraction angiography after embolisation with coils and vascular plug.

\section{Patient's perspective}

I am grateful for timely diagnostic studies and treatment during my hospital stay. At follow-up a month after the surgery, my symptoms had resolved.

\section{Learning points}

Pulmonary sequestration is a rare congenital malformation, but some patients can be diagnosed in adulthood.

- Pulmonary sequestration might be considered as a differential diagnosis in an otherwise healthy adult presenting with cough and haemoptysis.

- Endovascular embolisation followed by surgery can be a valid treatment approach in patients with pulmonary sequestration.

show any ischaemic changes. Testing showed unremarkable complete blood count, renal function, and electrolytes with a negative COVID-19 test. A computed tomographic angiography of the chest showed anomalous systemic arterial supply from the descending aorta to the left lower lobe basal segments (figure 1), a finding referred to intralobar lung sequestration (ILS). It also showed groundglass opacities and focal consolidation at the left lower lobe. Pulmonary angiogram redemonstrated the anomalous arterial supply. Embolisation with coils and vascular plug was successfully performed (figure 2). He was also treated with antibiotics to treat pneumonia. The patient was discharged 2 days after the procedure. A month later, he underwent an elective left lower lobectomy with ligation of the aortic arterial supply to the lesion. Although most patients with ILS present with recurrent respiratory infection, some may not have episodes of any pulmonary symptoms (including pneumonia) until adulthood, or may be identified incidentally in imaging studies. ${ }^{1}$

Contributors KS and NRK cared the patient. KS and YT wrote the manuscript.

Funding The authors have not declared a specific grant for this research from any funding agency in the public, commercial or not-for-profit sectors. 
Competing interests None declared.

Patient consent for publication Consent obtained directly from patient(s).

Provenance and peer review Not commissioned; externally peer reviewed.

Case reports provide a valuable learning resource for the scientific community and can indicate areas of interest for future research. They should not be used in isolation to guide treatment choices or public health policy.
ORCID iD

Yasuharu Tokuda http://orcid.org/0000-0002-9322-8455

\section{REFERENCE}

1 Gabelloni M, Faggioni L, Accogli S, et al. Pulmonary sequestration: what the radiologist should know. Clin Imaging 2021;73:61-72.

Copyright 2021 BMJ Publishing Group. All rights reserved. For permission to reuse any of this content visit https://www.bmj.com/company/products-services/rights-and-licensing/permissions/

BMJ Case Report Fellows may re-use this article for personal use and teaching without any further permission.

Become a Fellow of BMJ Case Reports today and you can:

- Submit as many cases as you like

- Enjoy fast sympathetic peer review and rapid publication of accepted articles

Access all the published articles

Re-use any of the published material for personal use and teaching without further permission

Customer Service

If you have any further queries about your subscription, please contact our customer services team on +44 (0) 2071111105 or via email at support@bmj.com.

Visit casereports.bmj.com for more articles like this and to become a Fellow 